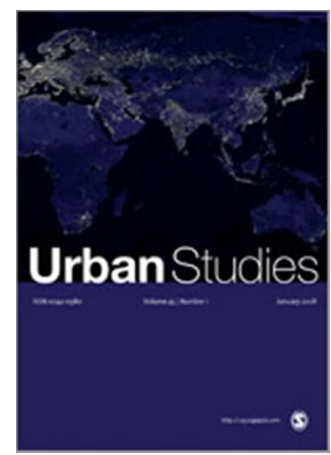

\title{
Canaries in the Mine? Gay Community, Consumption, and Aspiration in Neoliberal Washington, D.C.
}

\begin{tabular}{|c|c|}
\hline Journal: & Urban Studies \\
\hline Manuscript ID & CUS-707-16-08.R1 \\
\hline Manuscript Type: & Special Issue \\
\hline $\begin{array}{r}<\mathrm{b}>\text { Discipline: Please select a } \\
\text { keyword from the following list } \\
\text { that best describes the } \\
\text { discipline used in your paper.: }\end{array}$ & Geography \\
\hline $\begin{array}{r}\text { World Region: Please select } \\
\text { the region(s) that best reflect } \\
\text { the focus of your paper. } \\
\text { Names of individual countries, } \\
\text { cities \& economic groupings } \\
\text { should appear in the title } \\
\text { where appropriate.: }\end{array}$ & North America \\
\hline $\begin{array}{l}\text { Major Topic: Please identify up } \\
\text { to two topics that best identify } \\
\text { the subject of your article.: }\end{array}$ & Community, Neighbourhood \\
\hline $\begin{array}{r}\text { Please supply a further } 5 \\
\text { relevant keywords in the fields } \\
\text { below:: }\end{array}$ & homonormativity, consumption, gay, neoliberalism, United States \\
\hline
\end{tabular}

\section{SCHOLARONE ${ }^{\text {m }}$ \\ Manuscripts}




\title{
Canaries in the Mine? Gay Community, Consumption, and Aspiration in Neoliberal Washington, D.C.
}

\begin{abstract}
Gay men have been implicated in neoliberal urban development strategies (e.g., the creative city) as a 'canary' population that forecasts growth. Paradoxically, both the neoliberal re-development of North American inner-cities and the ways in which gay men become neoliberalized as individuals contributes to the fracture and dissolution of urban gay communities. In contrast to discourses of homonormativity, which suggests that gay men's declining attachments to gay communities stem from new equalities and consequent desires to assimilate into the mainstream, this article argues that gay men in D.C. have internalized neoliberal discourses that call for career development, home ownership and social hypermobilities. The narratives of 24 gay-identified men living in D.C., indicate that the social and spatial dissolution the gay community is framed by difficult-to-achieve aspirations, such as career advancement in a transient local economy, property ownership in an outof-reach market, and social status based on an ability to move through multiple neighbourhoods and venues with ease. As might be expected, African American and working class men are often left beyond the fray of these new ideals.
\end{abstract}

\section{Keywords}

gay, homonormativity, neoliberalism, consumption, United States

\section{Introduction}

Sexuality and space researchers recently have examined changes in the form and function of urban gay spaces. So-called gay villages now have more heterosexual residents (Reynolds 2009; Ghaziani 2014), significant gay venues have closed in many cities (Mattson 2015), there is a growing gay presence in the suburbs (Tongson 2011) and new 'gay-friendly' (though not necessarily gayspecific) neighbourhoods are emerging in urban peripheries (Gorman-Murray and Waitt 2009; Nash and Gorman-Murray 2014; Kanai and Kentamaa-Squires 2015). The 'preferences' of the gay 
community are often positioned as a causative link in the changing landscape of gay residential and commercial spaces. For example, same-sex couples are often described as preferring older, more expensive rental properties and distinctive non-child amenities that drive them to new areas when old gay neighbourhoods become desirable for 'mainstream' populations (Black et al. 2002; Collins et al. 2004; Ruting 2008; Cooke and Rapino 2007). Many have also suggested that new generations of gay men view older community spaces as tacky and passé and are consuming in other hip and edgy areas (Ruting 2008; Hayslett and Kane 2011; Nash 2013; Whittemore and Smart 2015).

These shifting choices and aspirations are often described as homonormative (Brown 2012). In what Duggan (2002) calls 'the new homonormativity' gay men and other sexually non-normative individuals are ushered into the fold of the capitalist mainstream through the conferral of equal rights and social acceptance. The notion of homonormativity reinforces the notion of preference as the driver of gay community dissolution, assuming that middle-class gay men and lesbians - once given the opportunity — will aspire to assimilate and abandon efforts to work across difference in their communities (Duggan 2002; Nast 2002; Richardson 2005). Many, however, have critiqued the homonormativity's tacit assumptions that gay men are adopting conservative, assimilative identities (Noble 2012) or purposely disavowing gay community life (Brown 2012; DiFeliciantonio 2015), noting that these assumptions are not easily applied to gay men who are not middle-class, white, or situated in metropolitan areas (Sothern 2004; Oswin 2005; Brown 2009, 2012). 
In fact, gay men are grappling with the same increasing pressures of career, financial insecurity, and uncertain social standing as other residents of the neoliberal city. Many aspects of their lives may be even be rendered even more difficult by ongoing homophobia. Although the homonormativity script also focuses on consumption aspects of the so-called 'pink economy' (Bell and Binnie 2004), gay men are also part of a pink work force negotiates still-uneven landscapes of workplaces and property markets in order to acquire so-called pink goods (Lewis and Mills 2016). As Gavin Brown notes, "queer critiques of homonormativity are frequently and problematically at odds with the lives and aspirations of many lesbians and gay men" (2012, p. 1067). This article therefore argues that the changing patterns and choices in gay men's lives often described by homonormativity are actually the products of neoliberalism and neoliberal urban development specifically. Generally understood as the variegated collection of policies and practices that promote austerity, competitiveness, and capital accumulation, neoliberalism can be understood as the logic the guides the operationalisation of modern urban development (Brenner et al. 2010).

The 'creativity city' discourse that took hold in many North American cities in the early and mid2000s is one trope that may illuminate the relationship between neoliberal imperatives for urban growth and the consumption choices of gay men. Popularised by Florida $(2002,2005)$, the creative city thesis offers a framework for attracting knowledge sector workers through amenities and qualities (e.g., diversity) that are appealing to 'creative' people. Critics, however, have claimed that it cannot predict urban growth trends or provide a meaningful, sustainable basis for urban policy interventions (Peck 2005; Markusen 2006). Many have also claimed that the attempts to 
operationalize the creative city theory through the development of high-end housing and amenities has actually exacerbated inequality in many cities (Catungal et al. 2009) and that its relevance to urban policy has since declined (Peck 2012). This article is therefore less concerned with the creative city as a valid urban growth theory than as a 'mobile political rationality' (Ong 2007) in which gay men are implicated as a pivotal population. Florida described the 'canary' metaphor accordingly in 2002 (Dreher 2002):

Gays are the canaries of the creative economy. Where gays are will be a community - a city or a region - that has the underlying preconditions that attract the creative class of people. Gays tend to gravitate toward the types of places that will be attractive to many members of the creative class. That said, a high score on the gay index, for example, New Orleans or Miami, does not translate into being a creative center, unless you couple that with technology assets. It's not that gays predict high-tech growth, it's that gays signal an environment that would attract creative-class people from a variety of backgrounds.

Many have debated the relevance of sexuality to the creative city concept. Since tolerance is measured simply by the presence of male same-sex coupled households and other 'minority groups' (e.g., immigrants) gay men act as 'tracking molecules' for growth potential (Storper and Scott 2009) but do not necessarily create development or inclusion (Parker 2008; Wimark 2014). In fact, just as canaries help to detect a powerful but invisible force that also ultimately kills them, neoliberalism has contributed to the fracturing of urban gay communities.

The logic of neoliberalism affects gay communities directly through land development but also through the vectors of individual gay lives. For example, policies and practices that deny permissions for establishing gay festivals, promote 'family-friendly' events, and develop properties 
geared to young families with children are central to the goal of deriving maximum profitability from urban spaces. (Doan and Higgins 2011; Mattson 2015; Kentamaa-Squires 2015). Venues in gay neighbourhoods, including those purchased by heterosexual buyers, may seek to attract whatever group has the most spending power and interest in an area at any given point in time (Binnie and Skeggs; Mattson 2015; Kanai and Kentamaa-Squires 2015). In other locales, creative city strategies have spurred the development of 'new' (though not necessarily inclusive) gay spaces as a means of 'catching up' with cities where they have developed more organically. In Singapore, where same-sex marriage and male same-sex activity is still illegal, the government has sponsored a Pride festival and marketed workplaces as gay friendly in order to attract educated foreign talent (Yue 2007; Oswin 2012). In Italy, where same-sex marriage is illegal and same-sex relationships were recognized legally only in 2016, similar 'exceptions' have been made (e.g., encouraging private entrepreneurs to create a 'gay street' in Milan prior to Expo 2015) in order to attract capital and cultivate a reputation as diverse and vibrant (DiFeliciantonio 2015). These interventions create ephemeral and professionalised gay and lesbian spaces but not necessarily a sustained gay community where activist spaces can flourish.

Like other urban residents, gay men are also affected individually by the internalization of competitive enterprise as a behavioural model (Foucault 2008; Dardot and Laval 2014). In fact, the manic search for excellence and elimination of defects that characterizes this model may be exacerbated in gay men because they are overcoming past traumas involving discrimination at home or in previous workplaces (Lewis and Mills 2016). Gay men who are enjoying new work and 
social opportunities in cities that voice acceptance may therefore feel particularly 'indebted' and constantly engage in 'work on oneself' to maintain this status (Di Feliciantonio 2016). To do so, they may strive to accumulate capital by investing in properties with gaps between real and potential value rather than attaching themselves to a specific community or neighbourhood (Smith 1987; Knopp 1990; Collins 2004). In addition, the pressures to maintain and advance careers among gay men may leave little time or energy for the social reproduction of their local communities (Lewis and Mills 2016). The neoliberalization of both urban development and individual gay lives are therefore mutually reinforcing. As Kaika and Ruggerio (2015) show, declining loyalties to local communities and the social fractures within them that are spurred by neoliberalism are also a precondition for the advancement of further neoliberal development strategies in cities. In the following sections, I argue that the consequent dissolution of a centralised gay neighbourhood and substantive gay community in D.C. is not due to both urban development strategies and the neoliberal subjectification of gay men themselves through three processes: the creation of neoliberal dispositions in the city's gay work force, perceived pressures to own property, and the emerging hypermobilities of gay social life.

\section{Methodology}

This article employs the life course narratives of 24 gay-identified men living in Washington, D.C., U.S.A., to better understand how gay men's individual consumption choices relate to both neoliberal urban development and the shifting spatialities of the gay community. The approach of interviewing gay men addresses several gaps in the literature on urban development and gay 
communities. First, it differs from previous interventions that have used 'interlocutors' such as property developers (Knopp 1990), real estate listings (Whittemore and Smart 2015) and gay businesses (Kanai and Kentamaa-Squires 2015) to describe shifts in gay consumption patterns. The narrative approach therefore offers a more emic perspective on what Knopp (1990) called the 'social production of demand for land and housing' in gay neighbourhoods and 'the material and class interests involved in gay community development.' Second, this approach corrects what Mattson (2007) called a "saloon problem" in urban ethnography, in which researchers examine the publicly visible aspects of social issues without examining the choices or thought processes of the individuals involved in those issues.

Participants were between 24 and 46 years old, had incomes between $\$ 40,000$ and $\$ 100,000$, and were recruited through respondent-driven sampling beginning with four men of different ethnoracial and professional subjectivities. Most worked in sectors such as education, politics, and health care, though often for government employers. Sixteen of the participants were white, three were African American, three were East or Southeast Asian, and two were Latino. Lasting 45-90 minutes, the interviews focused on linkages between migration, life course, and wellbeing. While much of each interview focused on decisions to settle in Washington, D.C., most of the participants also spoke extensively about their homes, social lives, and the changing characteristics of the neighborhoods where these were situated. Interviews were coded using an open approach (Charmaz 2006), emphasising the reasons behind (1) moves to D.C., (2) residential locational decisions, and (3) commercial consumption decisions. The analysis shows how individual migration, locational, 
and consumption decisions among gay men operate within broader constellations of power, (in)security, and inclusion that privilege certain behaviours, identities, and dispositions. Put differently, their choices are not just described through discourses about urban development and gay livelihoods but actively shaped by these discourses and the material changes they precipitate.

\section{Creating Neoliberal Dispositions in Gay D.C.}

During the past 10 years, D.C. has climbed to the top of the rankings of metropolitan concentrations of same-sex couples in the United States (Peters 2013) and continued to hold status as one of the country's premier 'creative cities' (Florida 2012). In 2003, the district government—set on increasing the city's population by 100,000 — embarked on a public-private marketing campaign for single professionals called 'city living, dc style' after opting out of alternate plans to focus on middle-class families (Gibson 2015). Privately managed business improvement districts (BIDs) such as Capital Riverfront and NoMa (North of Massachusetts Avenue) were created in neighbourhoods to develop land, provide additional beautification and security services, and market new properties (Schaller and Modan 2005; Modan 2008; Lewis 2010; Rolnik 2013). By 2013, the city had grown by 45,000 , most of the new residents were white and middle-class, and many were moving into houses or new condominium developments in transitional, rapidly gentrifying central and east-of-center neighbourhoods such as Shaw, Columbia Heights, and Navy Yard (O'Connell 2012). In addition, the average price of a single-family home in D.C. increased from about $\$ 250,000$ to over $\$ 400,000$ during the same time period and the number of low-cost rental units had halved (Gibson 2015). 
Since 2013, many of the last vestiges of the original Dupont Circle 'gayborhood' have disappeared (Giambrone 2016). Many of the historic and gay-specific shops along Connecticut Avenue and 17th Street (e.g., Lambda Rising bookstore, Chaos nightclub) in Dupont closed due to rent costs in the decade following implementation of the 'city living, dc style' plan. In addition, a smaller commercial space in southeast D.C. comprising more overtly sexualized gay spaces in the city (Ziegfeld's and Wet strip clubs) dissolved when the properties were purchased by the developers of the new stadium for the Washington Nationals baseball team (see Leap 2009). Following these developments, shifts in residential and commercial gay space have been rapid-fire and often shortlived in nature, with neighbourhoods such as Logan Circle, Columbia Heights, and even far-flung Takoma Park being named — sometimes simultaneously — as the next 'up and coming' gay neighbourhood in D.C. (Borderstan 2012; Giambrone 2016).

Although several dispersed gay venues remain, a new gay commercial cluster has not necessarily emerged. Many participants expressed a sense of disappointment over not finding the vibrant, visibly marked community in Dupont that they thought they would.

I guess it wasn't as gay as I thought it was ... Dupont Circle just seemed like a normal part of town to me ... there weren't rainbow flags everywhere ... it wasn't like you see on television ... San Francisco, guys walking down the street in leather chaps ... when you walk through Dupont there are a couple of sex shops that are a ... little flagrant about it - I put that in quotes - but I don't think there's that sense of 'in your face' ... I mean the only time you see things like that are at the Gay Pride Parade where people feel more free to express themselves and that's one time where it's encouraged and expected. (Marcus, 27, white). 
You've seen a lot of the old centres of gay culture here dissolve ... Lambda Rising [bookstore] closed, the Blade [newspaper] closed ... some of that is probably due to a generational shift as much as it is just shifts in D.C. ... it insulated people from a lot of really bad things (Max, 31, white)

As Nash and Gorman-Murray (2014) observe, these types of spatial shifts in gay and lesbian communities are not new, and the notion of gay community as a spatially concentrated 'ethnic minority' did not emerge until the 1980s and 1990s. Their work on Toronto and Sydney reveals that the 1950s and 1960s were also periods of significant mobilities between private homes and marginal neighbourhoods. D.C. is no different in this respect. The repression of homosexuality in the McArthur-era 1950s and 1960s meant that gay men working for the government often hid their identities and socialised in nondescript bars around P Street, west of Dupont Circle (Johnson 2004). Dupont Circle did not become an important emblem of gay D.C. following the movement of thousands of gay men into the peripheral neighbourhood in the 1980s and 1990s (see Myslik 1996). The goal is in this article is therefore not to valorize the concentrated 'gayborhood' as inherently better than more diffuse gay spaces, but to show that social and spatial hypermobilities in which gay men in D.C. are currently embroiled are products of both neoliberal development in D.C. and the neoliberal selves that are cultivated there. Moreover, many of the participants indicate that the shifting spatialities and competitive nature of the community are as often sources of stress and fatigue as they are enjoyment.

Today, the most recognizable and enduring institutions of gay D.C. are political, most notably the Whitman Walker Clinic — a national leader in HIV/AIDS activism — and the national gay rights organization Human Rights Campaign. D.C.'s research universities (e.g., Georgetown, George 
Washington, American), in addition to drawing creative professionals of their own (e.g., professors, graduate students) have also spawned consulting groups, think tanks and non-governmental organizations (NGOs) that work in tandem with government agencies. Despite the ascendancy to 'creative city' status that has spurred on mass gentrification and neoliberal urban development, D.C. does not have a particularly creative economy compared to 'classic' creative cities such as San Francisco. According to locational quotients from the Bureau of Labor Statistics (2015), D.C. is predictably less specialized in architecture and engineering based on locational quotients (1.1 vs. 1.3), but more specialized in education (1.02 vs. .88) and, surprisingly, both computer and mathematical professions (2.5 vs. 2.0) and the arts (1.7 vs. 1.5) (BLS 2015). These statistics, however, cannot account the distinction between private and governmental work, the latter of which accounts for $38 \%$ of the D.C. workforce.

In this respect, many gay men in D.C. fit the 'creative' mold nominally but are also neoliberal subjects attempting to fit their own aspirations within the constraints of their publicly-funded and party-affiliated employers to whom they feel indebted for their jobs (see also Lewis 2012; Lewis and Mills 2016). Adam (34, white) suggested that gay men to some extent have internalised the notion of the responsible 'gay creative':

Gay men tend to be attracted more toward, um, jobs in politics ... academic institutions ... government, too, perhaps, but there's no like industrial feel to the city at all, there's no manufacturing at all ... I think gay men tend to be attracted more toward like the ... creative kinds of jobs, not creative in the sense of like art. 
D.C.'s emergence as a destination of choice for gay men, then, might owe to the influx of men from regions (e.g., the South, the Midwest) where more accepting work environments were also those within lower-paying sectors such as food service, entertainment, and aesthetics (Murray 1996; Lewis and Mills 2016). Many of the participants suggested that D.C. is increasingly framed by media and marketing materials as place to build a career rather than a sustained community, and that individual gay men have internalised this discourse.

[National gay publication] Out magazine just had this 25 all-star guys in Washington ... like you have a white guy from Iowa who will come in and now he's working at the white house and will say people are friendly because everyone's a migrant, no one's from here ... it seems sort of insulting when people say all the gay guys are from somewhere else (Marc, 35, white)

A lot of people here are overachievers. I think that they're personally kind of insecure and these are not free thinkers ... basically someone's serf on the hill or in an association, even if you have a lot of delegated power (Carl, 43, African American).

People come from America, generally supported by their parents, to go to law school or to become like a government tool. It's kind of like being trapped in junior high forever (Randy, 39, white).

In this sense, the discourse of D.C. as a creative city cultivates personal aspirations for career advancement among gay men, which are in turn spurred on by the insecurities of a contracting economy and uneven work opportunities.

\section{Residential Decisions}

Economists have typically argued that gay men, and especially couples, make residential decisions based on preferences for certain neighbourhood amenities such as stylish housing and nightlife 
(Black et al. 2002). Sexuality researchers, in contrast, have typically suggested that these decisions are influenced by the gravitational pull of established gay neighbourhoods that incidentally include these amenities (Gorman-Murray 2007; Lewis 2014). While both of these theories tend to position gay men as empowered agents, their residential choices are increasingly encumbered the contracting land and housing markets of a rapidly re-developing inner city D.C. Since the early 2000s, the 'city living, d.c. style' plan and BID implementation have focused on what Rolnik (2013) calls inter-spatial competition and "the creation of new opportunities for speculative investments in central-city real estate markets and the construction of megaprojects intended to attract corporations" (p. 1063). In turn, home ownership in cities such as D.C. is seen as a necessary but increasingly out-of-reach means of both achieving social mobility and surviving economic instability (Aalbers 2008; Aalbers and Christopher 2014). Among gay men, it has become another arena for competition, self-improvement, and the pursuit of social mobility through both status and entertaining opportunities. The once-accessible rental market has become equally exploitative and this has become clear along generational lines as younger gay men try to establish careers and livelihoods in large cities (Aalbers and Christopher 2014).

In the past 10 years concentrations of gay residents in Northwest D.C. neighbourhoods such as Logan Circle and Columbia Heights have diffused outward into newly gentrifying areas. In the American Community Survey, 2005-2009 5-year estimate data shows the highest concentrations of same-sex couples in Logan Circle, Columbia Heights, and other Dupont-adjacent neighbourhoods (see Figure 1). This first distribution mirrors the contact diffusion model of cities 
such as Dallas-Fort Worth (Whittemore and Smart 2015), where proximity to other neighborhood with high concentrations of same-sex couples is one of the most important predictors of neighborhood choice for same-sex couples. In the 2010-2014 estimate, however, same-sex couples seem to follow the scattered front lines of gentrification in D.C. more generally (see Figure 2). Moderately high concentrations in Logan Circle and Columbia Heights persist, but fewer tracts in D.C. fall into the highest quintile of concentration. More same-sex couples now appear in newly redeveloping neighbourhoods such as Shaw, NoMa, Mount Vernon Triangle, which are still in somewhat close proximity to Dupont but where business improvement districts have facilitated the influx of brand new businesses and condominium developments (see also Schaller and Modan 2005; Lewis 2010). Even more striking is the relative decline of same-sex couples in the wealthiest neighbourhoods of Northwest D.C. (e.g., Cathedral Heights, Palisades, Friendship Heights) and their increase in formerly lower-income, higher-crime neighbourhoods to the east such as Petworth and Capitol Hill North, where the NoMa BID is located. This shift over a short period time suggests that gay men are increasingly pursuing less expensive housing in areas with some amenities. Insert Figures 1 and 2 here

The outward shift in same-sex couple residences could still be read as economic. With arguably fewer attachments to specific neighbourhoods (e.g., children in schools) compared to heteronormative families, gay men can pursue the most cost-effective housing opportunities. There's a whole dispersal that might have to do with the new sense of freedom (Max, 31, white). 
Dupont transitioned and got gentrified ... and then Logan gentrified and everybody wanted to go to Logan but then didn't and now they're in Columbia Heights but not quite ... so I think there's a whole dispersal, which in an interesting way might have to do with the new sense of freedom that like, does the gay community ultimately have to cloister or be in a ghetto once their rights are more protected? (Adam 34, white)

Others suggest, however, that a sense of inclusion and belonging are still important preconditions of residential decisions.

Once people have families, they worry about the school system and there's a lot more incentive to live outside the district, so I think a lot of gays stay central and don't have that next step to move back to the burbs. (Mark, 27, white).

While Adam suggests that a growing sense of freedom and safety has allowed gay men to move into more peripheral neighbourhoods, Mark indicates that the Maryland and Virginia suburbswhich are cheaper than D.C. in many cases - still remain an unattractive option for men who are not part of heteronormative family forms. Gay men, then, in theory have greater freedom to move around in a D.C. landscape that is increasingly accepting, but are still constrained by both the financial realities of the D.C. housing market and the more uncertain social and political landscape beyond the borders of the District.

Additional narratives reveal diverse aspirations and constraints among different men of different age and ethno-racial subjectivities. Among older home buyers, residential choices were also related to cost, but also the perceived need to invest in property among gay professionals in D.C.

Some of that has to do with property values, it's just in [Dupont Circle, Logan Circle, and Columbia Heights] property's so expensive that it's easier if you 
want to buy a house and make an investment to go out further than those areas. (Dave, 33, white)

You're not gonna make a lot of money in D.C. in a lot of other ways, so people want to make money on gentrification. (Jim, 34, white).

Both narratives suggest that the limited ability for gay men to buy property in the traditional gay neighbourhood has created a culture of expansion into cheaper areas. At the same time, the lack of incentive for gay men to live in the suburbs creates a preference for gentrifying inner-city neighbourhoods. Interestingly, some Black participants perceived greater acceptance for both sexual and racial diversity in out-of-centre areas, preferring historically Black middle-class areas (e.g., Montgomery County, Maryland) to either new suburban hubs or gentrifying inner-city areas.

... I told [my partner] when we bought a house we were not buying it in the district ... it just seemed to me like wasting money and there was such a huge difference moving to the suburbs ... but if you were to live in Loudon County [Virginia], I think [being gay] would be an issue ... I think if you lived outside of Prince George's or Montgomery County in Maryland it's also a problem. (Carl, 43, African American)

Carl's narrative suggests that while gay white home buyers have joined the rapid gentrification of inner-city D.C., African American men-including those who were raised in or near D.C.-may continue to see the city centre as homophobic.

Young renters, however, still understood Dupont Circle to be D.C.'s gay destination neighbourhood indicated a desire to live in or near that neighbourhood (see also Whittemore and Smart 2015).

When I first moved here I felt much more part of the gay community because of Dupont ... my apartment was close to places I wanted to be ... It's definitely nice to live somewhere I can go and be with my people. (Jake, 30, white). 
I could kind of define myself as part of a group in D.C. ... as a gay man living in Dupont Circle in the gaybourhood. (Jim, 27, Asian)

Ideally, I think most people would want to live in Dupont, but it just isn't affordable. (Jason, 26, white)

Interestingly, many younger participants also tended to claim detachment from the gay community despite wanting to live in or near the historic gay neighborhood. Mark (27, white), for example, initially described the gay community more as a political entity than a place to live.

The [gay community's] efforts to garner more rights for our community affects me every day and is great, but I don't know that the gay community affects my daily goings-on. (Mark, 27, white).

Later in the interview, however, he explains why he chose to move to Dupont once he established his career despite previously living in a cheaper neighborhood.

I was really excited ... I was going to be near the places I liked to go out, near the places where I knew other friends lived and other people that frequented those places lived ... so there was no resistance on my part to move from Shaw to Dupont. (Mark, 27, white)

Mark echoes Modan's (2008) observations about the growing fetishism of diversity in D.C. rather than actual inclusion or engagement with diverse communities. While he wants to live near amenities associated with the gay community he presents the gay community itself as immaterial to his day-to-day life.

In contrast, working class newcomers and long-term African American residents often lack the education and professional status to rent in established gay neighbourhoods or aspire to home ownership in the rapidly gentrifying areas of the central city. David (42, Asian) described some 
acquaintances living in suburban Virginia who lacked the economic freedom to climb the D.C. property ladder and never gained access to a stable gay social circle.

... My friends tending bar fresh out of the army, like they couldn't integrate so they left. On the socioeconomic level, these guys would be at the bottom here, and they were not native to Washington-so it was hard for them to get a foothold beyond the bar that they worked at, which had a sense of community but not enough to sustain them. There's nothing, really nothing else for them here.

David's narrative reinforces the point that rapidly developing creative cities necessarily have winners and losers. When individual competition and commodified diversity is embraced by the gay community of that city, it loses the cross-class sociability and interaction that characterised the early gay neighbourhoods of the 1970s and 1980s (Mattson 2015). While younger men may temporarily live in known gay neighbourhoods and develop aspirations of buying elsewhere once professional and personal networks are cemented, others remain on the spatial and social periphery.

\section{Social Lives}

Gay men's social lives increasingly reveal a similar tension between desires for belonging and a disposition of detachment from the gay community (see Nash 2013). In part, these tensions are related to the structural reconfiguration of the gay scene. Many participants suggested that business owners in D.C. had changed their business models to 'neighbourhoodbased' bars rather than gay bars.

The bars have kind of moved out, they're not just in one central area anymore, they're kind of in different parts of the city and we've seen a lot more mixed bars now. It used to be that gay would go to gay bars and straights would go to straight bars ... any night of the week $25,50 \%$ of the people are straight ... so I 
think the bars are more neighbourhood-based now than anything ... One of the [mixed bars] I've gone to is called Wisdom, down in Southeast. It's kind of an area that's up and coming now. It's kind of ... it's a martini bar, basically ... any night of the week, if you go there, you'll, you'll get a whole mix of gay and straight people ... one of the owners is gay and one of the owners is straight, so it's ... kind of a fun place to go (Adam, 34, white).

While some enjoyed the some enjoyed the social mobility provided by mixed and 'gay-friendly' bars or private fundraisers, others acknowledge that this mobility was only afforded to professional, middle-class patrons who are 'in the know.'

Being a white male certainly helps and, you know, I'm not poor by any means ... I'm able to hang out in the posh parts of town if I want to and I can be trendy if I want to (Marcus, 27, white).

Although sexuality and race were traditional dividers in D.C.'s nightlife scene, Marcus' narrative suggests that class is becoming the new marker in gentrified, neoliberal D.C. (see also Mattson's 2015 study of gay bars San Francisco).

At the same time, the closure of gay bars in D.C. cannot be fully explained by new preferences for sexually mixed spaces. In fact, dissatisfaction with the gay scene was a far more frequent theme across the interviews. Some perceived the old Dupont neighbourhood as outmoded and stereotypical.

You walk around Dupont and everyone is so, I don't want to say flamboyant ... they try to play up the stereotype ... not only the pride parade but if you walk down $17^{\text {th }}$ Street or around Dupont circle, that's not me. (Devon, 27). 
Although Devon's comment could be read as the disaffection of a younger generation, other narratives suggest that many are becoming disenchanted with the gay scene because of its increasingly professional, career-driven nature.

The mainstream gay bars serve a similar networking function to ... bars that cater to specific industries ... There's so much push onto like what is your career portfolio in this city ... that actual emotional value and moral value, all those things are pretty secondary ... A city like Washington [is] turning over every four years ... the pressure of that is hitting the gay community even more (David, 42, Asian)

People come here because they have this urge to be the student class president forever, and cause they're so focused on work and figuring out who can help [them] become student class president forever, people are much more cliquish ... there aren't places where you can just kind of go and like hang out and do fun stuff. (Randy, 39, white).

Other participants saw private political and fundraising events as typical forms of socialising for gay men in D.C., but saw these as equally exclusive to the bar scene rather than viable alternatives.

The biggest criticism of [Human Rights Campaign] was that it was all catered to upper middle class white men and I guess a lot of the D.C. crowd is that. They're college educated, they have good jobs, and they rent or own a condo, and they have designer stuff, and they go out all the time. (Jake, 30, white).

All of the narratives indicate that the old neighborhood scene and the increasingly popular fundraiser scenes have becomes ways to develop networking opportunities and assert one's elite status within the gay community rather than to build community. Gay bars and fundraisers thus become transactional spaces where business deals are made or where pre-existing social groups choose to go after work or a private party. In particular, the trope of the 'class president' — which arose in five of 24 interviews - suggests an unwillingness to compartmentalise or downsize professional aspirations in favour of a more balanced lifestyle of greater community engagement. 
Many may also avoid the gay scene once they have the individual professional and financial freedom to pursue social alternatives.

[In the early 2000s] I was trying to adjust to the city, I didn't feel very good about how I looked ... my impression at the time was [that men at D.C. gay bars were] very wrapped up in themselves, very clannish ... I basically went to bars to hook up and that was it ... [Now my boyfriend and I] end up actually just doing a lot of stuff at home ... it's really kind of pointless to go to [local gay bar] if you're in no way interested in most of the people (Jason, 30, white).

Jason seems to reflect back the exclusion he once perceived at gay bars by foreclosing the possibility of making new friends or acquaintances within those settings. In this sense, gay scene decline and home ownership aspirations work in tandem, though not necessarily in the way that the classic homonormativity script imagines. Jason suggests that creeping neoliberalism has rendered D.C.'s gay scene just a place to meet a partner or build a professional network, which in turn makes it an unpleasant and exclusive social space. The private home, in turn, becomes a refuge from these unpleasant social spaces once the transactions of the scene are completed. The ideal social scenario for gay men in D.C., then, might be to have access to traditional gay bars as an emblem of acceptance or source of nostalgia but to not have to rely on them for socialising. Much like the D.C. labour market, its gay nightlife too is characterised by a fly-in, fly-out culture more concentrated on key venues than on a collective gay space.

In a third body of narratives, participants explained that the top-down re-development of certain areas of the city (e.g., the creation of Nationals Park baseball stadium in Southeast D.C.) had 
systematically disadvantaged working class men and men of colour. The former collection of businesses in the Navy Yard neighbourhood of Southeast D.C., while characterised as the tawdrier side of gay nightlife, were also a more racially mixed alternative to Dupont (see Leap 2009). In some cases, the men of colour who patronised those bars have moved to village bars no longer preferred by middle-class white men.

Gay businesses have shut down because of the baseball stadium, that whole section closed down, Chaos on $17^{\text {th }}$ Street closed down, which a lot of people of colour went to ... I think because places shut down - [nearby gay bar] Cobalt to me is a perfect example-like I remember the first time I went, everyone was all white ... there was one night we were joking, we think there are more people of colour here than there are white people. (Paul, 27, African American)

Many black men, however, have gravitated to the single traditionally African American bar left in Washington, D.C.

Bachelors' Mills, I understand that it's a lot busier than it ever has been-and that's the black bar, which is right on Capitol Hill in Barracks' Row. I've been there a couple of times. It is truly an African-American bar, and it's where African American men go to meet African American men and that's who's there ... It's busier than it has been, and that has to be-because depending on who you are and what your comfort level is-you might not want to walk into JR's and you certainly might not want to walk into JR's by yourself (Carl, 43, African American)

Interestingly, these narratives suggest that the more diffuse commercial landscape of the new gay

D.C. did not necessarily offer the tolerance and diversity espoused by the creative city thesis

(Florida 2002, 2005) or the more inclusive alternatives to the traditional gay village observed elsewhere (Nash 2013; Nash and Gorman-Murray 2014). Instead, men of colour have lost some of their key social spaces and segregation has become further retrenched as white, economically established men aspire to socialise in private and professional spaces. While mobilities across urban 
space may now be a more important form of sexual citizenship for gay men and lesbians than territorial belonging (Nash and Gorman-Murray 2014), the narratives suggest that these new mobilities are not always inclusive or even always pleasurable.

\section{Conclusions}

The narratives here provide insights into the relationships between neoliberalism and urban gay communities. They suggest frustration with an increasingly aspirational culture among gay men that calls for professional advancement, social networking in desirable locations (e.g., at fundraisers, on trips), and the freedom to consume freely within the fragmented landscape of gentrifying D.C. The culture of aspiration, however, is neither a simple matter of choice nor a wholesale onslaught of homonormativity brought about by changes in gay rights. Rather, it appears rooted in development strategies that drive the cost of living upward, exert financial pressure upon gay and other 'minority' communities, and encourages competition and fragmentation within those communities. Gay residential choices and social lives therefore become entwined with individual aspirations that are increasingly difficult to meet.

Queer geographers have often described gay men as allies of state institutions 'complicit' in capitalist projects (Nast 2002), and it would be easy to suggest that gay men in D.C. are emblematic of this trend. At the same time, one must consider the individual life trajectories that bring gay men to cities like Washington, D.C. Although gay men naturally seek out opportunities in a local 
economy where they are valued and accepted, they are also inculcated into a local culture that prioritizes individual and competitive modes of consumption. While spatial concentration may have represented the best way for gay men to achieve social standing and political power in the $1980 \mathrm{~s}$ and 1990s (Knopp 1990), individual flexibility and widespread social connectedness are more important in the neoliberal city. In this milieu, a sense of gay community may be an important precondition for moving to the city, but not necessarily central to daily livelihoods (see also Modan 2008). In fact, many participants seemed to worry that being seen as overly invested in or reliant upon the gay community would paint them as socially or professionally deficient.

The pressures of competition for jobs, housing, and social status in D.C. have affected both residential choices and social lives of gay men in the city. Similar to other moderately sized cities such as Columbus and Dallas (Hayslett and Kane 2011; Whittemore and Smart 2015), gay men in Washington, D.C., are increasingly moving to gentrifying neighbourhoods near the geographic center of the city (e.g., Shaw, Fort Totten, Petworth, Brookland) despite previously being concentrated in neighbourhoods immediately adjacent to Dupont (Adams Morgan, Mount Pleasant, Logan Circle, Columbia Heights) and out-of-center middle-class areas such as Takoma Park and Palisades. These residential choices may represent opportunistic investment strategies but also reduced opportunities for home ownership in a constrained housing market.

Socialising across different segments of the gay community in D.C. also appears decreasingly common. While many of the bars in Dupont Circle had once served a more mixed (though still 
segregated) clientele, they were increasingly dominated by gay white professionals by the 2000 s but have subsequently been discarded by white middle-class men who began to see them as too exclusive and unwelcoming. While a new proliferation of 'gay-friendly' bars cater to middle-class professionals, socialising has also become more difficult for those who cannot afford transportation costs to more dispersed venues, tickets to get into events and fundraisers, or homes in which to entertain. In addition, venues that accrued status over time as comfortable places for African American, Latino, and working class men have closed. In many cases, gay men of colour have taken over 'traditional' gay bars while white men have bunkered into increasingly privatised spaces.

While Florida's (2002) ‘canary’ metaphor originally referred to gay men as harbingers of urban economic development, gay men living in neoliberal cities such as D.C. may now be 'canaries' of late-stage neoliberalism that constrains and divides cities through unequal housing markets and increasingly competitive, precarious workplaces. Suffused with aspiration to advance their careers in livelihoods, gay men in D.C. are at least partially reacting to the discourses of urban development that surround them in newspapers, lecture halls, and social media. In this sense, the fragmentation of once-concentrated gay communities (i.e., the death of the canaries) may signal that neoliberal development strategies are beginning to destroy the very subjects they once valorised. At the same time, neoliberalism is not all-encompassing, and it does not always produce homonormativity. Many gay men feel an allegiance to early gay activists, engage in gay community work, and express frustration over the lack of inclusivity in its current, fragmented iteration. Further work might seek to measure the relationships between gay community dispersal and other urban development 
processes, as well as investigate gay men's methods of coping with community fragmentation.

Doing so will require continuing to read for local difference in the broad landscape of shifting gay sexualities and spatialities.

\section{Funding}

Government of Canada >

Social Sciences and Humanities Research Council of Canada

770-2009-0053

\section{References}

Aalbers, MB. 2008. "The Financialization of Home and the Mortgage Market Crisis." Competition \& Change 12(2): 148-1866.

Aalbers MB, Christophers B. 2014. "Centering Housing in Political Economy." Housing, Theory \& Society 31(4): 373-394.

Bell D, Binnie J. 2004. “Authenticating queer space: Citizenship, urbanism, and governance.” Urban Studies 41(9): 1807-1820.

Binnie J, Skeggs B. 2004. "Cosmopolitan knowledge and the production and consumption of sexualized space: Manchester's gay village.” The Sociological Review 52(1): 39-61.

Black D, Gates G, Sander SG and Taylor SJ. 2002. "Why do Gay Men Live in San Francisco?" Journal of Urban Economics 51: 54-76.

Brenner, N, Peck J, Theodore N. 2010. Variegated neoliberalization: geographies, modalities, pathways. Global Networks 10(2): 182-222.

Brown G. 2009. "Thinking beyond homonormativity: performative explorations of diverse gay economies." Environment and Planning A 41(6): 1496-1510. 
Brown G. "Homonormativity: a metropolitan concept that denigrates 'ordinary' gay lives." 2012. Journal of Homosexuality 59(7): 1065-1072.

Brown M. 2014. “Gender and Sexuality II: There goes the gayborhood?” Progress in Human Geography 38(3): 457-465.

Brown-Saracino, J. 2009. A Neighbourhood that Never Changes: Gentrification, Social Preservation, and the Search for Authenticity. Chicago: University of Chicago Press.

Bureau of Labor Statistics (BLS). 2015. Occupational Employment Statistics for Metropolitan Areas. http://www.bls.gov/oes/.

Catungal JP, Leslie D, Hi Y. Geographies of Displacement in the Creative City: A Case Study of Liberty Village, Toronto. Urban Studies 46(5-6): 1095-1114.

Collins A. 2004. "Sexual Dissidence, Enterprise, and Assimilation: Bedfellows in Urban Regeneration." Urban Studies 41(9): 1789-1806.

Cooke TJ, Rapino M. 2007. "The Migration of Partnered Gays and Lesbians between 1995 and 2000.” The Professional Geographer 59(3): 285-297.

Dardot P and Laval C. 2014. The New Way of the World: On Neoliberal Society. London: Verso Books.

DiFeliciantonio C. 2015. "The Sexual Politics of Neoliberalism and Austerity in an 'Exceptional' Country: Italy." ACME 14(4): 1008-1031.

Doan PL, Higgins H. 2011. "The Demise of Queer Space? Resurgent Gentrification and the Assimilation of LGBT Neighbourhoods." Journal of Planning Education and Research 31: 6-25.

Dreher C. 2002. "Be Creative_-Or Die." Salon, 7 June.

http://www.salon.com/2002/06/06/florida_22/.

Duggan L. 2002. "The new homonormativity: The Sexual politics of neoliberalism." In: Castronovo $\mathrm{R}$ and Nelson DD (eds.) Materializing Democracy: Toward a revitalized cultural politics. Durham, NC: Duke University Press, pp. 175-194. 
Florida R. 2002. The Rise of the Creative Class: And How It's Transforming Work, Leisure, Community and Everyday Life. New York: Basic Books.

Florida R. 2005. Cities and the Creative Class. New York: Routledge.

Florida R. 2012. “America's leading creative class metros.” The Atlantic CityLab, July 9. http:/www.citylab.com/work/2012/07/americas-leading-creative-class-metros/2233/.

Foucault M. 2008. The Birth of Biopolitics: Lectures at the College de France, 1978-1979. New York: Palgrave Macmillan

Giambrone, A. 2016. "D.C. No Longer Has a Central Gay Neighborhood. Does That Matter?" Washington City Paper, June 2.

Gibson, T.A. "The rise and fall of Adrian Fenty, Mayor-Triathlete: cycling, gentrification and class politics in Washington DC. Leisure Studies 34(2): 230-249.

Ghaziani, A. 2014. There Goes the Gayborhood? Princeton, NJ: Princeton University Press.

Halperin, D. 2014. How to Be Gay. Cambridge, MA: Harvard University Press.

Hayslett KL, Kane MD. 2011. “'Out' in Columbus: A geospatial analysis of the neighbourhoodlevel distribution of gay and lesbian households." City \& Community 10(2): 131-156.

Johnson DK. 2004. The Lavender Scare: The Cold War Persecution of Gays and Lesbians in the Federal Government. Chicago: University of Chicago Press.

Kanai JM, Kentamaa-Squires K. 2015. "Remaking South Beach: metropolitan gayborhood trajectories under homonormative entrepreneurialism." Urban Geography 36(3): 385-402.

Knopp L. 1990. "Some theoretical implications of gay involvement in an urban land market." Political Geography Quarterly 9(4): 337-352.

Leap W. 2009. "Professional baseball, urban restructuring and (changing) gay geographies in Washington, D.C." In: Out in Public: Reinventing Lesbian/Gay Anthropology in a Globalizing World. New York: Blackwell, pp. 202-222.

Lewis NM, Mills S. Seeking Security: Gay Labour Migration and Uneven Landscapes of Work. Environment and Planning A. DOI: 10.1177/0308518X16659773. 
Lewis, NM. Grappling with Governance: The Emergence of Business Improvement Districts in a National Capital. Urban Affairs Review 46 (2): 180-217.

Lewis NM. 2012. "Gay in a 'Government Town': the settlement and regulation of gay-identified men in Ottawa, Canada." Gender, Place and Culture 19(3): 291-312.

Mattson G. 2015. "Style and the value of gay nightlife: homonormative placemaking in San Francisco." Urban Studies 52(16): 3144-3159.

Mattson G. 2007. Urban Ethnography’s “Saloon Problem” and Its Challenge to Public Sociology. City \& Community 6(2): 75-94.

McChesney C. 2005. "Cultural Displacement: Is the GLBT Community Gentrifying African American Neighborhoods in Washington, D.C.?” The Modern American Spring: 24-27.

Markusen, A. 2006. "Urban development and the politics of a creative class: evidence from a study of artists." Environment and Planning A 38: 1921-1940.

Modan G. 2008. "Mango Fufu Kimchi Yucca: The Depoliticization of 'Diversity' in Washington, D.C. Discourse.” City \& Society 20 (2): 188-221.

Murray SO. 1996. American Gay. Chicago: University of Chicago Press.

Myslik W. 1996. Renegotiating the social/sexual identities of places: gay communities as safe havens or sites of resistance? In: Duncan N. (ed.) Bodyspace. Routledge, London, pp. 156-169.

Nash CJ. 2013. "The age of the 'post-mo'? Toronto's gay village and a new generation." Geoforum 49: 243-252.

Noble G. 2012. Spaces of Privilege. Doctoral Thesis, University of Brighton.

O'Connell J. 2012. "D.C.'s growth is fueled by 20-somethings: can the city grow up with them?" The Washington Post, May 25.

Nash CJ, Gorman-Murray AW. 2014. “LGBT Neighbourhoods and 'New Mobilities': Towards Understanding Transformations in Sexual and Gendered Urban Landscapes.” International Journal of Urban and Regional Research 38(3): 756-772. 
Nast HJ. 2002. "Queer patriarchies, queer racisms, international.” Antipode 34 (5): 874-909. Oswin N. 2012. "The Queer Time of Creative Urbanism: Family, Futurity and Global City Singapore." Environment and Planning A 44 (7): 1624-1640.

Ong A. 2007. "Neoliberalism as a mobile technology." Transactions of the Institute of British Geographers 32(1): 3-8.

Peck J. 2005. Struggling with the creative class. International Journal of Urban and Regional Research 29: 740-770.

Peck J. 2012. "Recreative City: Amsterdam, Vehicular Ideas and the Adaptive Spaces of Creativity Policy." International Journal of Urban and Regional Research 36 (3): 462-485.

Podmore J. 2013. “Lesbians as village 'queers': The transformation of Montreal's lesbian nightlife in the 1990s." ACME 12(2): 220-249.

Reynolds R. 2009. "Endangered territory, endangered identity: Oxford Street and the Dissipation of Gay Life. Journal of Australian Studies 33(1): 79-92.

Richardson D. 2005. "Desiring Sameness? The Rise of a Neoliberal Politics of Normalisation."

Rolnik R. 2013. Late Neoliberalism: The Financialization of Homeownership and Housing Rights. International Journal of Urban and Regional Research 37: 1058-1066.

Ruting B. 2008. "Economic transformations of urban gay spaces: Revisiting Collins' evolutionary gay district model." Australian Geographer 39: 259-269.

Schaller S, Modan G. 2005. "Contesting Public Space and Citizenship: Implications for Neighbourhood Business Improvement Districts." Journal of Planning Education and Research 24 (4): 394-407.

Storper M, Scott A. 2009. "Rethinking human capital, creativity and urban growth." Journal of Economic Geography 9: 147-167.

Tongson K. 2011. Relocations: Queer Suburban Imaginaries. New York: New York University Press. 
Whittemore AH, Smart MJ. 2015. "Mapping gay and lesbian neighborhoods using home advertisements: Change and continuity in the Dallas-Fort Worth Metropolitan Statistical Area over three decades." Environment and Planning A DOI: 10.1177/03085I8X15605095.

Wimark T. 2014. "Is It Really Tolerance? Expanding the Knowledge about Diversity for the Creative Class." Tijdschrift voor economische en sociale geografie 105 (1): 46-63.

Yue A. 2007. "Hawking in the Creative City." Feminist Media Studies 7 (4): 365-380. 


\section{Percentage of unmarried partner households: Same sex}
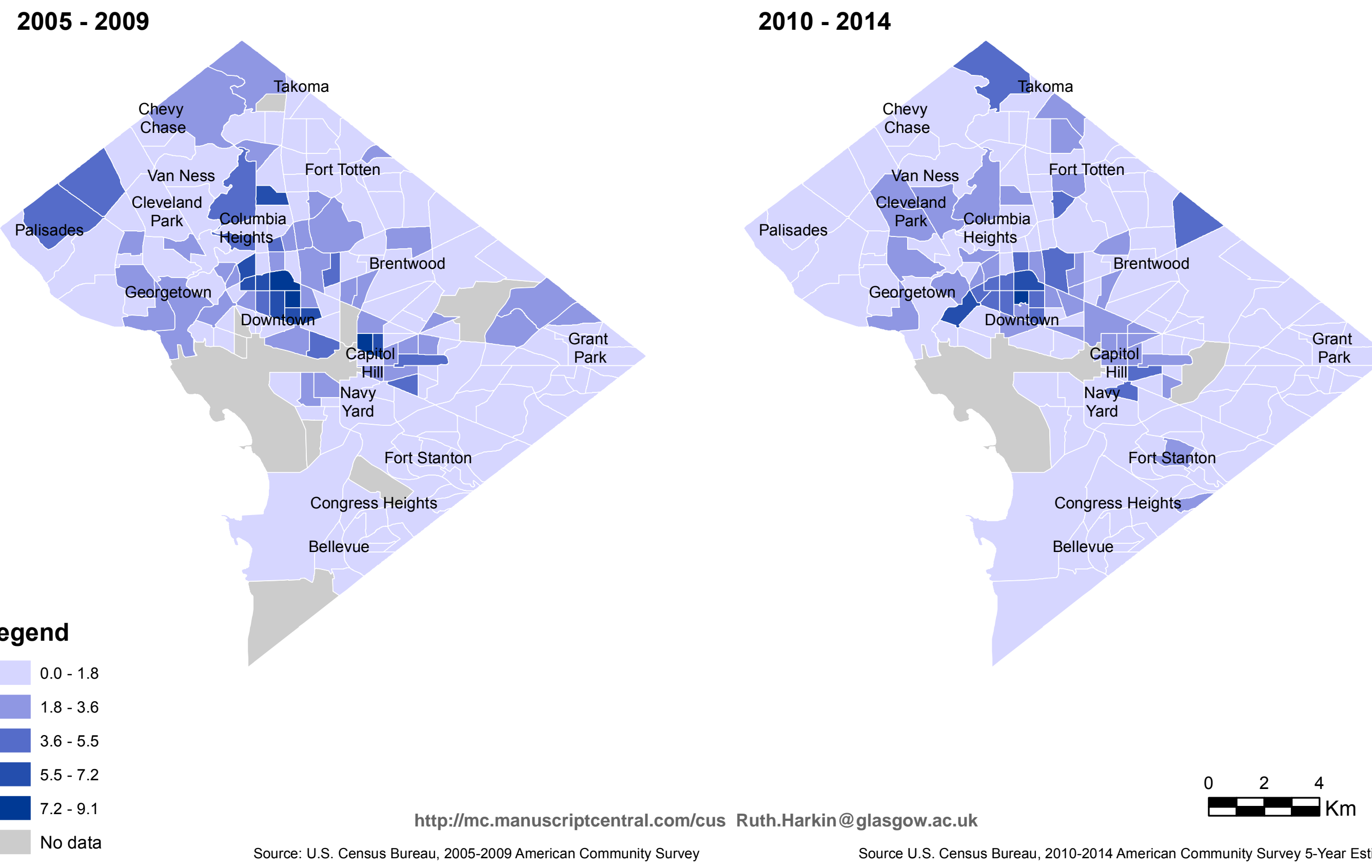

http://mc.manuscriptcentral.com/cus Ruth.Harkin@glasgow.ac.uk

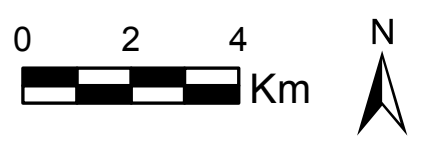

